\title{
Stabilization of Mercury in Sediment by Using Biochars under Reducing Conditions
}

\author{
Peng Liu ${ }^{\mathrm{a}}$, Carol J. Ptacek ${ }^{*, a}$, David W. Blowes ${ }^{\mathrm{a}}$, Y. Zou Finfrock ${ }^{\mathrm{b}, \mathrm{c}}$, Robert A. Gordon ${ }^{\mathrm{b}, \mathrm{c}, \mathrm{d}}$ \\ ${ }^{a}$ Department of Earth and Environmental Sciences, University of Waterloo, 200 University Ave. \\ W., Waterloo, ON, Canada, N2L $3 G 1$ \\ ${ }^{b}$ CLS@APS sector 20, PNCSRF, Argonne National Laboratory, 9700 S. Cass Avenue, Argonne, \\ Illinois 60439, USA. \\ ${ }^{c}$ Science Division, Canadian Light Source Inc., 44 Innovation Boulevard, Saskatoon, \\ Saskatchewan, Canada S7N 2 V3 \\ ${ }^{d}$ Department of Physics-Simon Fraser University, 8888 University Drive, Burnaby, BC, Canada, \\ V5A $1 S 6$
}

\section{Abstract}

Mercury $(\mathrm{Hg})$ is widely distributed in different localities around the world and poses a serious health threat to humans, especially when ingested in the form of methylmercury (MeHg). Efforts have been directed toward decreasing the production of $\mathrm{MeHg}$ by converting $\mathrm{Hg}$ to stable forms. Activated carbon and biochar have been evaluated as stabilization agents for $\mathrm{Hg}$ in contaminated sediments. However, the longterm fate of $\mathrm{Hg}$ stabilized by these materials remains unclear. Here, we compare the effectiveness of $\mathrm{Hg}$ stabilization using two biochars prepared from switchgrass at $300^{\circ} \mathrm{C}$ (low T) and $600^{\circ} \mathrm{C}$ (high T). Experiments were conducted by co-blending biochars and sediment for $>600 \mathrm{~d}$ under anaerobic conditions. Aqueous concentrations of total $\mathrm{Hg}$ and $\mathrm{MeHg}$ were greatly reduced in the presence of biochars, with the exception of a spike in MeHg concentration observed at $440 \mathrm{~d}$ in the high- $\mathrm{T}$ biochar system. Hg co-occurs with $\mathrm{S}, \mathrm{Fe}, \mathrm{Cu}$, and other elements within the plant structure of low-T biochar particles, but primarily on the outer surfaces of high-T biochar particles. Our results indicate that the

\footnotetext{
* Corresponding author address: Department of Earth and Environmental Sciences, University of Waterloo, 200 University Ave. W., Waterloo, ON, Canada N2L 3G1. Tel: +01 (519) 888 4567, ext. 32230

E-mail: ptacek@uwaterloo.ca
} 
stabilization of $\mathrm{Hg}$ may be through an early-stage diagenetic process, suggesting that the stabilization of $\mathrm{Hg}$ by biochar may be effective over long time frames.

Key words: biochar; mercury; x-ray absorption spectroscopy; confocal x-ray microfluorescence imaging; early diagenesis

\section{Introduction}

$\mathrm{Hg}$ is widely distributed in the environment, and poses serious health risks to humans. $\mathrm{MeHg}$, an organic form of $\mathrm{Hg}$, is much more toxic than inorganic $\mathrm{Hg}$ and can cause central nervous system defects [1]. Inorganic forms of $\mathrm{Hg}$ can be converted to MeHg by microbes under anaerobic conditions (e.g., sediments and wetlands) [2-5], especially in the benthic zone of lakes, rivers, and oceans just below the oxic/anoxic interface [6]. Many efforts have focused on decreasing the direct release of $\mathrm{Hg}$ and the production of MeHg by dredging Hg-contaminated sediment [7], in situ capping [8], or by converting $\mathrm{Hg}$ to less bioaccessible forms [9-11]. Pyrogenic carbonaceous materials, including activated carbon, are widely used for Hg removal from aqueous solutions [12] and less extensively for $\mathrm{Hg}$ stabilization in sediments $[10,11]$.

Biochar, a type of black carbon with properties similar to charcoal, is a low-cost alternative to activated carbon. Biochar can be produced on site and can be used as a soil amendment to improve soil fertility [13], to sequester carbon [14, 15], and in water and soil treatment applications [16].

Despite the increasing utilization of biochar for water treatment [12] and stabilization in contaminated sediments [11], the long-term fate of $\mathrm{Hg}$ after uptake by biochars remains unclear. We hypothesize that amending contaminated sediment with biochar can reduce aqueous concentrations of $\mathrm{Hg}$ and $\mathrm{MeHg}$ and can convert a fraction of the $\mathrm{Hg}$ to stable forms within the biochar particles. We also hypothesize that the degree 
of uptake by the biochar is dependent on the pyrolysis temperature used to prepare the biochar. Our specific objective was to investigate the correlation between filtered total $\mathrm{Hg}$ ( $\mathrm{THg}$ ) and $\mathrm{MeHg}$ with 1) the evolution of aqueous indicators of biogeochemical processes (e.g., $\mathrm{Fe}, \mathrm{SO}_{4}{ }^{2-}$, organic carbon); 2) the evolution of microbial communities; and 3) the changes in binding environment and distribution of $\mathrm{Hg}$ within the biochars after extended reaction times.

In addition to conventional X-ray absorption spectroscopy (XAS) measurements, confocal X-ray micro-fluorescence imaging (CXMFI), which is an emerging nondestructive technique [17], was employed. CXMFI provides compositional and structural information from precise locations on the surface of, and within, intact particles, with greater spatial precision than can be obtained using conventional micro x-ray fluorescence $(\mu-X R F)$ methods [18]. Limited applications of CXMFI are reported for natural materials; examples include the characterization of Se accumulation in fish eye lens [19]; W, Pt, and Fe in particles embedded in a mineralogical matrix [20]; K, Ca, and Fe in rice grains [21]; and $\mathrm{U}-\mathrm{Th}-\mathrm{Pb}$ for dating of geological materials [22].

Two biochars prepared at 300 and $600{ }^{\circ} \mathrm{C}$ from switchgrass, a widely available material in North America, were selected for co-blending with Hg-contaminated sediment and river water under anaerobic conditions. Samples of the aqueous and solid phases were collected as a function of time to determine shifts in chemical composition, microbial population, and $\mathrm{Hg}$-binding environment through XAS measurements.

\section{Materials and Methods}

\subsection{Materials}

The sediment was collected from South River, Virginia, $5.6 \mathrm{~km}$ downstream of a historical point $\left(38^{\circ} 3^{\prime} 49.00^{\prime \prime} \mathrm{N}, 78^{\circ} 53^{\prime} 4.65^{\prime \prime} \mathrm{W}\right)$ of $\mathrm{Hg}$ release. The river water was 
collected $300 \mathrm{~m}$ upstream of this location. Raw switchgrass was air dried and pyrolyzed for biochar using a kiln at either 300 or $600{ }^{\circ} \mathrm{C}$ for $2-3 \mathrm{~h}$ under $\mathrm{O}_{2}$-deficient conditions [23].

\subsection{Microcosm Experiment}

Microcosm experiments were conducted by mixing biochar, sediment, and river water at a ratio of 1:20:160 (5:100: $800 \mathrm{~g})$ in amber bottles. Controls included ultra-pure water, river water, sediment mixed with river water, and biochar mixed with river water. The sediment control was duplicated. The experiments were conducted in an anaerobic glovebox.

Unfiltered aqueous samples were collected for analysis of $\mathrm{pH}$ and Eh, and samples filtered using $0.45-\mu \mathrm{m}$ membranes were collected for analysis of alkalinity, anions, cations, dissolved organic carbon (DOC), THg and MeHg. Sample splits were also filtered through $0.2-\mu \mathrm{m}$ membranes for $\mathrm{THg}$ analyses. Solid samples were collected periodically for $\mathrm{MeHg}$ and pyrosequencing analyses. Biochar particles were separated from the solid samples at $65,100,154,235,387$, and $600 \mathrm{~d}$.

\subsection{Chemical Analyses}

Determinations of $\mathrm{pH}$ were made using a Ross combination $\mathrm{pH}$ electrode (Orion 815600, Thermo Scientific). Determinations of Eh were made using a Pt combination Eh electrode (Orion 9678, Thermo Scientific), checked against ZoBell's [24] and Light's [25] solutions. Alkalinity was determined using a Hach digital titrator using bromocresol green-methyl red as an indicator. Concentrations of anions (including short-chain organic acids) were determined using ion chromatography (ICS-5000, Dionex Corp.) with an IonPac AS11 4×250 mm column. Cation concentrations were analyzed by inductively 
coupled plasma-optical emission spectrometry (Thermo Scientific iCAP 6500) and inductively coupled plasma-mass spectrometry (Thermo Scientific XSeries II). DOC was determined using an automated wet chemical oxidation method (Aurora 1030, OI Analytical).

Concentrations of $\mathrm{THg}$ were determined using a cold vapour atomic fluorescence spectroscopy technique (CVAFS, Tekran 2600), following EPA method 1631, with a method detection limit (MDL) of $0.2 \mathrm{ng} \mathrm{L}^{-1}$. MeHg in the aqueous phase was analyzed through distillation (Tekran 2750), aqueous ethylation, and purge and trap using the CVAFS technique (Tekran 2700) following EPA method 1630. Determination of MDL for $\mathrm{MeHg}$ was performed for each run and an average MDL of $0.02 \mathrm{ng} \mathrm{L}^{-1}$ was calculated. Solid samples for $\mathrm{MeHg}$ analyses underwent distillation by mixing with a solution containing $20 \% \mathrm{KCl}$ and $8 \mathrm{M} \mathrm{CuSO}_{4}$ to improve recovery [26].

The C/S content of the sediment and biochar was analyzed using a resistance furnace (Eltra CS-2000) and elemental composition was obtained following EPA Method 3052. The total organic carbon (TOC) of the sediment was analyzed using a segmented flow analyser (Skalar, Netherlands) following EPA Standard Method 5310C.

\subsection{Pyrosequencing Analysis}

Genomic DNA was isolated and purified from solid-phase samples using commercial extraction kits (UltraClean Soil DNA Kit; MO BIO Laboratories). Purified DNA was shipped to MR DNA Laboratory (Shallowater, Texas) for pyrosequencing analysis. Detailed information on the selected primers (515/806 for bacteria and archaea), the processes and conditions of polymerase chain reaction and sequencing, and data processing procedures is provided in the Supporting Information. Fermenters, iron- 
reducing bacteria $(\mathrm{FeRB})$, sulfate reducing bacteria $(\mathrm{SRB})$ and methanogens were extracted from the pyrosequencing results. Potential $\mathrm{Hg}$ methylators were also extracted based on the methylators identified by Oak Ridge National Laboratory [27] (Table S1).

\subsection{X-Ray Absorption Spectroscopy}

The separated biochar particles were prepared as thin-sections $(26 \times 26 \mathrm{~mm}$ in size and $30 \mu \mathrm{m}$ thick). Micro-XRF maps were collected from thin-sections on Beamline 13ID-E GSECARS and 20-ID-B PNC/XSD of the Advanced Photon Source. A focused beam $\sim 2 \times 2 \mu \mathrm{m}^{2}$ and step size of $2 \mu \mathrm{m}$ were used for the $\mu$-XRF map collection. A photon energy of $12.6 \mathrm{keV}$ was applied for $\mu$-XRF maps of $\mathrm{Hg}, \mathrm{Cu}, \mathrm{Mn}, \mathrm{Fe}, \mathrm{Zn}, \mathrm{Ni}, \mathrm{Ca}$, and $\mathrm{K}$ and of $2.5 \mathrm{keV}$ for $\mathrm{S} \mu$-XRF maps. Areas with elevated $\mathrm{Hg}$ intensity were identified for acquisition of extended X-ray absorption fine structure (EXAFS) spectra. The EXAFS spectra of $\mathrm{Hg}$ were processed using Athena, and EXAFS model calculations were made using Artemis [28] following the methods described by Gibson et al. [29] and Liu et al. [30].

CXMFI of the $\mathrm{Hg}$-bearing biochar particles at $600 \mathrm{~d}$ was conducted at PNC/XSD. Biochar particles were separated from the mixture and washed three times using ultrapure water to remove fine sediment particles on the surface. Biochar particles were mounted on a quartz slide and oriented at $35^{\circ}$ to the incident beam (Fig. S1). The XRF spectra were monitored by a Si-drift Vortex detector placed at $90^{\circ}$ relevant to the incident beam. A Ge optical unit (lithographically fabricated spoked channel array) was mounted in front of the detector to complete the confocal geometry with a probing volume of $\sim 2 \mu \mathrm{m}[31$, 32]. 


\subsection{Correction Method for X-Ray Fluorescence Attenuation}

The intensity attenuation was calculated for the incident beam and XRF arising from the additional depth into the sample using the Beer-Lambert Law by modifying a method described by Choudhury et al. [19]. The equation $A=\ln \left(I_{0} / I\right)=\rho^{*} \sigma^{*} l$ was used to calculate the unknown $I_{0}$ and $I$ of each pixel in each elemental intensity map, where $A$ is absorbance, $I_{0}$ is incident intensity, $I$ is transmitted intensity, $\rho$ is particle density $\left(\mathrm{g} \mathrm{cm}^{-3}\right)$, $\sigma$ is the total absorbance cross section $\left(\mathrm{cm}^{2} \mathrm{~g}^{-1}\right)$, and $l$ is path length $(\mathrm{cm})$. The attenuation was calculated assuming the elemental mass distribution was proportional to the fraction of intensity for the corresponding element in each pixel over the intensity of the entire map. The density and elemental composition of the $\mathrm{Hg}$-bearing particles were estimated based on the density and elemental composition of the sediment and biochar particles (Tables S2-S3). The total absorbance cross section of each pixel was calculated using the McMaster table [33]. The method was verified by a NIST reference standard material (SRM 1834). Data importing, processing, and plotting were completed in MATLAB.

\subsection{Statistical Analysis}

The similarity of each parameter between the duplicated sediment controls was tested by conducting a $t$ test with a $95 \%$ confidence level $(P<0.05)$. A $t$ test was conducted to evaluate if $\mathrm{THg}$ and $\mathrm{MeHg}$ concentrations in the sediment controls were significantly different from the amended systems.

\section{Results and Discussion}

\subsection{Overview of Sediment, River Water, and Biochar}

The sediment selected for this study was collected from an $\mathrm{Hg}$-enrich area, and had contents of $\mathrm{Hg}, \mathrm{S}, \mathrm{Fe}, \mathrm{Cu}$ as $187,300,16,000$ and $150 \mu \mathrm{g} \mathrm{g}^{-1}$ (Table S2). The low-T and high-T biochars were rich in $\mathrm{C}(70.2$ and $94.5 \%)$ and relatively low in $\mathrm{S}(0.1$ and 
$0.55 \%$ ) (Table S3). The river water contained low concentrations of $\mathrm{THg}\left(<5 \mathrm{ng} \mathrm{L}^{-1}\right)$, $\operatorname{MeHg}\left(<0.02 \mathrm{ng} \mathrm{L}^{-1}\right)$, and other components (Table S4).

\section{2 pH, Redox Potential and Alkalinity}

Values of $\mathrm{pH}$ for the sediment control and amended systems gradually increased from $\sim 7.5$ to $\sim 9.0$ in the first $150 \mathrm{~d}$ and then decreased slightly to $\sim 8.5$ at day 445 . The redox potential (Eh) values for the sediment controls and amended systems decreased from $\sim 50$ to $\sim-420 \mathrm{mV}$ in the first $126 \mathrm{~d}$, then decreased further to $\sim-440 \mathrm{mV}$ at day 445 (Fig. S2). The Eh values indicate an anaerobic environment was maintained over the course of the experiment. The alkalinity concentrations increased from $\sim 50$ to $\sim 200 \mathrm{mg}$ $\mathrm{L}^{-1}$ before day 100 and then decreased to $\sim 50 \mathrm{mg} \mathrm{L}^{-1}$ at day 445 in sediment controls and amended systems.

\subsection{Aqueous THg and MeHg}

Filtered $(0.2 \mu \mathrm{m}) \mathrm{THg}$ concentrations initially increased as a function of time, ranging from 0.8 to $24 \mu \mathrm{g} \mathrm{L}^{-1}$ for sediment controls (Fig. 1) and peaking at day 182 in the high-T $\left(14 \mu \mathrm{g} \mathrm{L}^{-1}\right)$ and low-T $\left(6.6 \mu \mathrm{g} \mathrm{L}^{-1}\right)$ biochar amended systems. For sediment controls, the concentrations of $0.45-\mu \mathrm{m}$ filtered $\mathrm{THg}$ during the first $60 \mathrm{~d}$ increased from 2 to $40 \mu \mathrm{g} \mathrm{L}^{-1}$, decreased to $\sim 10 \mu \mathrm{g} \mathrm{L}^{-1}$ at day 100 , and then stabilized at $\sim 40 \mu \mathrm{g} \mathrm{L}^{-1}$ from day 130 for the remainder of the experiment. The $0.45-\mu \mathrm{m}$ filtered $\mathrm{THg}$ concentrations in the high-T and low-T amended systems were highly variable during the first $80 \mathrm{~d}$, then increased from $\sim 3$ to $\sim 30 \mu \mathrm{g} \mathrm{L}^{-1}$ from day 80 to 120 before decreasing to $\sim 11$ and $\sim 3 \mu \mathrm{g}$

$\mathrm{L}^{-1}$, respectively. THg concentrations were $<10 \mathrm{ng} \mathrm{L}^{-1}$ in the controls of ultrapure water, river water, and biochar. 
$\mathrm{MeHg}$ concentrations were low $\left(<5 \mathrm{ng} \mathrm{L}^{-1}\right)$ during the first $23 \mathrm{~d}$ (Fig. 1; enlarged in Fig. S3). After the lag phase, a pronounced increase was observed (first blue bar, Fig. 1), followed by a decline in concentrations and then a second spike (second blue bar, Fig. 1). For the two sediment controls, MeHg concentrations initially increased to $48 \mathrm{ng} \mathrm{L}^{-1}$ at day 37 and to $130 \mathrm{ng} \mathrm{L}^{-1}$ at day 47 , respectively. For the amended systems, the first increase of $\sim 12 \mathrm{ng} \mathrm{L}^{-1}$ was observed at day 100. A second increase in $\mathrm{MeHg}$ to $64 \mathrm{ng} \mathrm{L}^{-1}$ at day 265 and to $28 \mathrm{ng} \mathrm{L}^{-1}$ at day 387 was observed in the two controls, and to $27 \mathrm{ng} \mathrm{L}^{-1}$ for the low-T biochar amended system. A second peak in MeHg concentration of $260 \mathrm{ng}$ $\mathrm{L}^{-1}$ was observed at day 445 in the high-T amended system. This value is much greater than observed in the controls and low-T amended system. The MeHg concentrations were $<0.02 \mathrm{ng} \mathrm{L}^{-1}$ in the ultrapure water, river water, and biochar controls.

No significant differences were observed in the concentrations of $\mathrm{THg}$ and $\mathrm{MeHg}$ for the duplicated sediment controls $(P<0.5)$. The concentrations of $\mathrm{THg}$ and $\mathrm{MeHg}$ were significantly lower in the low-T amended system than the sediment controls. The concentrations of $\mathrm{MeHg}$ in the high-T amended system were significant lower than in the sediment controls for the first $200 \mathrm{~d}$.

The results indicate the addition of biochars resulted in lower $\mathrm{THg}$ and $\mathrm{MeHg}$ concentrations than in sediment controls, except the late $\mathrm{MeHg}$ concentration spike in the high-T amended system. The late $\mathrm{MeHg}$ concentration spike in the high-T amended system occurred without the addition of a new source of electron donors and acceptors. Concentrations of $\mathrm{THg}$ and $\mathrm{MeHg}$ in the low-T amended system were less than those in the high-T amended system. The results also show greater uptake of THg by the low-T 
biochar. This latter result contrasts observations from batch-style experiments by Liu et al. [30].

\subsection{Aqueous $\mathrm{Fe}$ and $\mathrm{SO}_{4}{ }^{2-}$}

Following a lag (23 d), Fe concentrations increased to maximum values of $\sim 1.3$ $\mathrm{mg} \mathrm{L}^{-1}$ for sediment controls and 0.7 for high-T and $3.5 \mathrm{mg} \mathrm{L}^{-1}$ for low-T biochar amended systems at day 100 , subsequently decreasing to $<0.2 \mathrm{mg} \mathrm{L}^{-1}$ after day 154 . $\mathrm{SO}_{4}{ }^{2-}$ concentrations decreased to $<0.05 \mathrm{mg} \mathrm{L}^{-1}$ after $79 \mathrm{~d}$ for sediment controls, and after 65 and $100 \mathrm{~d}$ for low-T and high-T biochar amended systems. No significant differences were observed in the concentrations of $\mathrm{Fe}$ and $\mathrm{SO}_{4}{ }^{2-}$ for the duplicated sediment controls.

The increase in $\mathrm{THg}$ concentrations, which correspondence to the increase in dissolved $\mathrm{Fe}$, is attributed to the dissolution of $\mathrm{Hg}$-bearing iron oxide solids originally in the sediment (Fig. 1; enlarged in Fig. S3) [34-36]. The decrease in $\mathrm{SO}_{4}{ }^{2-}$ concentrations correspond to a decrease in concentrations of $\mathrm{THg}$ and $\mathrm{Fe}$, which is likely due to the formation of $\mathrm{Hg}$ and $\mathrm{Fe}$ sulfide precipitates. The concentrations of $\mathrm{SO}_{4}{ }^{2-}$ were $<0.05 \mathrm{mg}$ $\mathrm{L}^{-1}$ after $\sim 75 \mathrm{~d}$, after which $\mathrm{THg}$ concentrations started to increase (Fig. 1; enlarged in Fig. $\mathrm{S} 3$ ). This increase in $\mathrm{THg}$ concentrations is likely due to the lack of formation of biogenic sulfide. This observation is consistent with a previous study [37], in which aqueous concentrations of $\mathrm{THg}$ were observed to be highly variable in response to redox oscillations in a microcosm experiment containing riparian soils.

\subsection{Solid-Phase MeHg}

The MeHg contents in the low-T system (20-100 $\left.\mathrm{ng} \mathrm{g}^{-1}\right)$ were greater than those in sediment controls (20-40 $\mathrm{ng} \mathrm{g}^{-1}$ ) at all times (Fig. 2). The MeHg contents in the high-T amended system were less than those in sediment controls before day 154; but, much 
greater than the controls after day 235 (up to $260 \mathrm{ng} \mathrm{g}^{-1}$ ). The high $\mathrm{MeHg}$ contents in the high-T system after day 235 correspond to the $\mathrm{MeHg}$ concentration spike in the aqueous phase (Fig. 1). The elevated $\mathrm{MeHg}$ contents in the amended systems were likely due to the adsorption of aqueous $\mathrm{MeHg}$ by biochars, which is consistent with previous studies $[10,11]$.

\subsection{Aqueous Carbon Source}

Different patterns in concentration shifts of DOC, acetate, and alkalinity were observed in the sediment controls and amended systems (Fig. 3). The concentrations of DOC increased from $\sim 2$ to $90 \mathrm{mg} \mathrm{L}^{-1}$ in the sediment controls and to $\sim 60 \mathrm{mg} \mathrm{L}^{-1}$ for the amended systems. The acetate concentrations peaked at $31 \mathrm{mg} \mathrm{L}^{-1}$ at day $\sim 100$ in the low$\mathrm{T}$ amended system and at $40 \mathrm{mg} \mathrm{L}^{-1}$ at day 200 in the sediment control and high- $\mathrm{T}$

amended system. The alkalinity concentrations increased from $\sim 50$ to $\sim 180 \mathrm{mg} \mathrm{L}^{-1}$ at day 100 for the sediment control, and to 260 and $200 \mathrm{mg} \mathrm{L}^{-1}$ at day 65 for low-T and high-T amended systems; alkalinity concentrations decreased to $\sim 50 \mathrm{mg} \mathrm{L}^{-1}$ at the termination of the experiment. No significant differences were observed in the concentrations of carbon sources for the duplicated sediment controls. The DOC and acetate are carbon sources for microbes, for example, FeRB, SRB, and methanogens. Alkalinity (including $\mathrm{HCO}_{3}{ }^{-}$and $\mathrm{CO}_{3}{ }^{2-}$ ) can be utilized as carbon energy sources by methanogens [38].

\subsection{Pyrosequencing Analysis}

The pyrosequencing results indicate the total percentages of fermenters, FeRB, SRB, and methanogens increased from $10 \%$ to up to $80 \%$ from day 0 to 387 in the sediment control and amended systems (Fig. 4a). The SRB only accounted for $<3.3 \%$ for all the systems. Methanogens appeared after 154 days, corresponding to the decrease in alkalinity. 
The results indicate the total percentages of potential methylators was $<0.5 \%$ in all samples (Fig. 4b). The total abundances show an increasing and then decreasing pattern in the sediment control and the amended systems from day 0 to 387 . The total abundances in the sediment control were lower than in the amended systems. At the beginning of the experiment, only Geobacter uraniireducens was observed. An increase in the abundance of species that are potential methylators was observed as the experiment progressed.

The early peak in $\mathrm{MeHg}$ concentrations is attributed to methylation of $\mathrm{Hg}$ by fermentative bacteria, FeRB, and SRB, as potential methylators were detected in the systems (Fig. 4b), and concentrations of Fe peaked and concentrations of $\mathrm{SO}_{4}{ }^{2-}$ decreased, corresponding to this MeHg peak (Fig. 1). The co-existence of FeRB and SRB methylators is consistent with a previous study using sediments from the same watershed [39]. The second peak in $\mathrm{MeHg}$ concentrations toward the end of the experiment is likely due to the activity of methanogenic methylators. Although methanogenic methylators reported in other studies (Table S1) were not observed in this study using the pyrosequencing method, other indications of methanogenesis were observed. Toward the end of the experiments, concentrations of $\mathrm{SO}_{4}{ }^{2-}$ were $<0.05 \mathrm{mg} \mathrm{L}^{-1}$ and aqueous $\mathrm{Fe}$ concentrations were stable, likely due to low activities of FeRB and SRB. Concentrations of alkalinity increased slowly and then decreased consistent with increased consumption of inorganic carbon due to methanogenic activity. Thus, the corresponding peak in $\mathrm{MeHg}$ may be associated with methanogenic methylators that have not yet been identified (Table S1). 


\section{8 $\mu$-XRF and EXAFS}

Micro-X-ray fluorescence ( $\mu$-XRF) mapping was applied to examine thin-sections prepared with biochar particles from the amended systems at 235 and $387 \mathrm{~d}$ (Fig. 5). The maps indicate the co-occurrence of $\mathrm{Hg}$ with $\mathrm{Cu}, \mathrm{Fe}, \mathrm{S}, \mathrm{Mn}, \mathrm{Zn}$, and other elements (Figs. S4-6). In the low- $\mathrm{T}$ biochar system, $\mathrm{Hg}, \mathrm{Cu}$, and $\mathrm{Fe}$ were distributed primarily on particle surfaces, but also penetrated into the solid phase (circled area); S was preferentially distributed along the measured planes. In the high- $\mathrm{T}$ biochar, $\mathrm{Hg}, \mathrm{Cu}$, and $\mathrm{Fe}$ were primarily distributed along the pore edges of the particles (Fig. 5; Figs. S5-6). Mapping of the particles by $\mu$-XRF for thin-sections of biochar particles collected at day 65,100 , and 154 was attempted, but the intensity of the XRF signal of $\mathrm{Hg}, \mathrm{Fe}, \mathrm{Cu}$, etc. was not distinguishable from the background.

To further understand the $\mathrm{Hg}$ binding environments (e.g., surrounding elements, coordination numbers) at the atomic level, $\mathrm{Hg}$ EXAFS spectra were collected from $\mathrm{Hg}$ rich area of the high-T biochar and from bulk biochar particles collected at $387 \mathrm{~d}$ (Fig. 5; Table 1). Modeling results indicate that the best fit for $\mathrm{Hg}$-rich area and bulk high- $\mathrm{T}$ biochar was obtained using metacinnabar $(\beta-\mathrm{HgS})$ as a model compound. The coordination numbers are 3.90 and 3.24 for the $\mathrm{Hg}$ rich area and bulk sample, and the bond length is $\sim 2.50 \AA$. For the bulk low-T biochar, the best fit was obtained using cinnabar $(\alpha-\mathrm{HgS})$ as a model compound. The coordination number is 1.93 and the bond length is $2.36 \AA$. The modelled values were close to those of the reference material (Fig. S7; Table S5).

The EXAFS modeling results indicate a fraction of the unstable forms of $\mathrm{Hg}$ released from the sediment likely converted to stable forms by interaction with biogenic 
sulfide and precipitation of cinnabar or metacinnabar. These analyses are consistent with the observed shifts in aqueous phase chemistry.

\subsection{Confocal X-Ray Micro-Fluorescence Imaging}

The fluorescence intensity measured using conventional XRF mapping represents the sum of information along the measurement path (thickness of the thin sections is 30 $\mu \mathrm{m})$ of the microbeam [18]. To overcome this limitation, CXMFI was conducted to provide spatial distributions of elements accumulated within the biochar particles at a finer scale. The porous structures of the low-T and high-T biochars collected from the amended system after $600 \mathrm{~d}$ can be identified using maps of $\mathrm{K}, \mathrm{Ca}$, and other elements, which are indicative of the source plant matter (Fig. 6; Figs. S8-9; Table S3). The maps indicate that $\mathrm{Fe}$ and $\mathrm{Hg}$ are distributed throughout the low- $\mathrm{T}$ intact biochar particles, and a similar distribution pattern was observed in a low-T biochar particle collected after 752 d (Fig. S10). The Fe and $\mathrm{Hg}$ are preferentially observed on the surface of the high-T biochar particles, which is consistent with measurements made on a high-T particle collected after $752 \mathrm{~d}$ (Fig. S11). These observations are consistent with maps of Ti, Cr, Mn, Co, Ni, Cu, Zn, and As (Figs. S8-11). The distribution of these elements is consistent with the structure of the intact biochar. The CXMFI results combined with $\mu$-XRF mapping indicate that the biochar accumulated $\mathrm{Hg}$ and other elements within its structure.

The co-occurrence of $\mathrm{Hg}, \mathrm{Mn}, \mathrm{Fe}, \mathrm{Co}, \mathrm{Cu}, \mathrm{Zn}$, etc. within the structure material of low-T and high-T biochar particles indicates secondary minerals were likely formed through a series of biogeochemical reactions and incorporated into the structure of the biochar (Sections 3.2-3.4 and 3.6). These observations also indicate the removal of $\mathrm{Hg}$ results from the precipitation of $\mathrm{Hg}$ sulfide phases. The following reactions likely 
occurred during the course of experiment (Equs. 1-3), based on the results of aqueous geochemical analysis and characterization of solid phase using synchrotron-based methods.

$$
\begin{array}{cc}
4 \mathrm{FeOOH}+\mathrm{CH}_{2} \mathrm{O}+8 \mathrm{H}^{+}=4 \mathrm{Fe}^{2+}+\mathrm{CO}_{2}+7 \mathrm{H}_{2} \mathrm{O} & \text { Equ. } 1 \\
\mathrm{SO}_{4}^{2-}+2 \mathrm{CH}_{2} \mathrm{O}+\mathrm{H}^{+}=\mathrm{HS}^{-}+2 \mathrm{CO}_{2}+2 \mathrm{H}_{2} \mathrm{O} & \text { Equ. } 2 \\
\mathrm{Hg}^{2+}+\mathrm{HS}^{-}=\mathrm{HgS}_{(s)}+\mathrm{H}^{+} & \text {Equ. } 3
\end{array}
$$

Previous studies report a size-exclusion effect on the adsorption of dissolved organic matter (DOM) to activated carbon [40-43], and the size of fine sediment (or clay) is greater than DOM, therefore these elements observed inside the structure material of biochar particles were not due to the fine sediment (or clay). The absence of $\mathrm{Hg}, \mathrm{Fe}, \mathrm{Cu}$, etc. associated with biochar particles collected at day 65, 100, and 154 indicates fine sediment (or clay) was also not attached to the biochar particles (Section 3.8).

Differences in elemental distribution patterns for low-T and high-T biochar particles are attributed to changes in the biochar composition and structure due to pyrolysis temperature. DOC and acetate determinations indicate the presence of higher concentrations and more rapid leaching of these compounds from biochar pyrolyzed at $300{ }^{\circ} \mathrm{C}$, and suggest that this material was not as completely carbonized as the biochar pyrolyzed at $600{ }^{\circ} \mathrm{C}$ (Fig. 3). These results suggest that low-T biochar particles are more easily penetrated by $\mathrm{Hg}, \mathrm{Mn}, \mathrm{Fe}, \mathrm{Co}, \mathrm{Zn}$, and other elements, which either precipitated or replaced the original elements within the particle.

Early diagenesis includes bacterial decomposition of organic matter, bacterial reduction of sulfate, dissolution and re-precipitation of minerals, bacterial regulated redox reactions, and diffusion of dissolved minerals in sediment [44]. The time scale for early 
diagenesis can be $<10$ years [45-47]. In this study, $\mathrm{Hg}$ is likely stabilized by the low-T and high-T biochars through similar early diagenetic processes.

Mercury was observed to co-occur with $\mathrm{Cu}, \mathrm{Fe}, \mathrm{S}, \mathrm{Zn}, \mathrm{Mn}$, and other elements within the low-T and high-T biochar particles. Biochar can remain stable in the environment over long time frames [48]. The deep penetration of $\mathrm{Hg}$ into the biochar structure and the possible presence of $\mathrm{Hg}$ as an insoluble sulfide phase suggest that the $\mathrm{Hg}$ contained in these particles may also be stable for long periods. We speculate that the uptake of $\mathrm{Hg}$ within the biochar structure may lead to a decrease in bioaccessibility and potentially a decrease in methylation of $\mathrm{Hg}$ present within biochar grains [49]. In addition, encapsulation of $\mathrm{Hg}$ within the biochar grains, as observed in our experiments, may limit its transport to other environmental compartments [50].

\section{Conclusions}

The results indicate the evolution of $\mathrm{Hg}$ and $\mathrm{MeHg}$ in the microcosm experiment is well correlated with the evolution of $\mathrm{Fe}, \mathrm{SO}_{4}{ }^{2-}$, $\mathrm{DOC}$, acetate, and alkalinity in the solution and microbes in the solid phase. The $\mu$-XRF and CXMFI analyses indicate $\mathrm{Hg}$ co-occurs with $\mathrm{Fe}, \mathrm{Cu}$, and other elements across the biochar particles. Low- $\mathrm{T}$ switchgrass biochar is likely an effective material for $\mathrm{Hg}$ stabilization in sediments and that the process leading to $\mathrm{Hg}$ stabilization is consistent with early diagenetic processes. These findings have ramifications not only for the long-term uptake of metals by biochar, but also the long-term sequestration of carbon through the potential decrease in reactivity of the biochar due to the accumulation of inorganic elements within the structure and an enhanced encapsulation process.

The microcosm experiment in this study was designed to simulate the application

of biochar in a setting representative of a stagnant riverine system with potential burial or 
mixing of the biochar with organic-rich sediment in a low advective setting. Initially, the system will be oxidized, but is may become more reducing over time. The microcosm study reported here covers a progressively reducing system, from initially oxidizing to $\mathrm{Fe}(\mathrm{III})$ and $\mathrm{SO}_{4}$-reducing to strongly methanogenic. Toward the end of the experiment, elevated MeHg concentrations were observed using high-T biochar, suggesting precautions may be required prior to application of biochar in highly reducing systems. These results suggest that biochar amendment should be evaluated for site specific conditions including sediment composition, physical setting, and biogeochemical conditions. 
Table 1. EXAFS fitting results.

\begin{tabular}{llllllll}
\hline Sample & Model & Path & $\mathrm{CN}$ & $\mathrm{R}(\AA)$ & $\mathrm{S}_{0}{ }^{2}$ & $\sigma^{2}\left(\AA^{2}\right)$ & $\mathrm{R}-$ factor \\
\hline High-T Spot & $\beta-\mathrm{HgS}$ & $\mathrm{Hg}-\mathrm{S}$ & $3.90 \pm 1.11$ & $2.50 \pm 0.03$ & $0.718^{\mathrm{a}}$ & $0.009^{\mathrm{a}}$ & 0.02 \\
Low T Bulk & $\alpha-\mathrm{HgS}$ & $\mathrm{Hg}-\mathrm{S}$ & $1.93 \pm 0.14$ & $2.36 \pm 0.01$ & $0.841^{\mathrm{a}}$ & $0.005^{\mathrm{a}}$ & 0.01 \\
High T Bulk & $\beta-\mathrm{HgS}$ & $\mathrm{Hg}-\mathrm{S}$ & $3.24 \pm 0.70$ & $2.49 \pm 0.03$ & $0.718^{\mathrm{a}}$ & $0.009^{\mathrm{a}}$ & 0.17 \\
\hline $\mathrm{CN}=$ coordination number; $\mathrm{R}=$ modeled bond length; $\mathrm{S}_{0}{ }^{2}=$ amplitude reduction factor, \\
$\sigma^{2}=$ mean-square radial displacement; R-factor = fitting statistic. ${ }^{\mathrm{a}}$ values obtained from \\
reference materials (Table S5; Fig. S7).
\end{tabular}




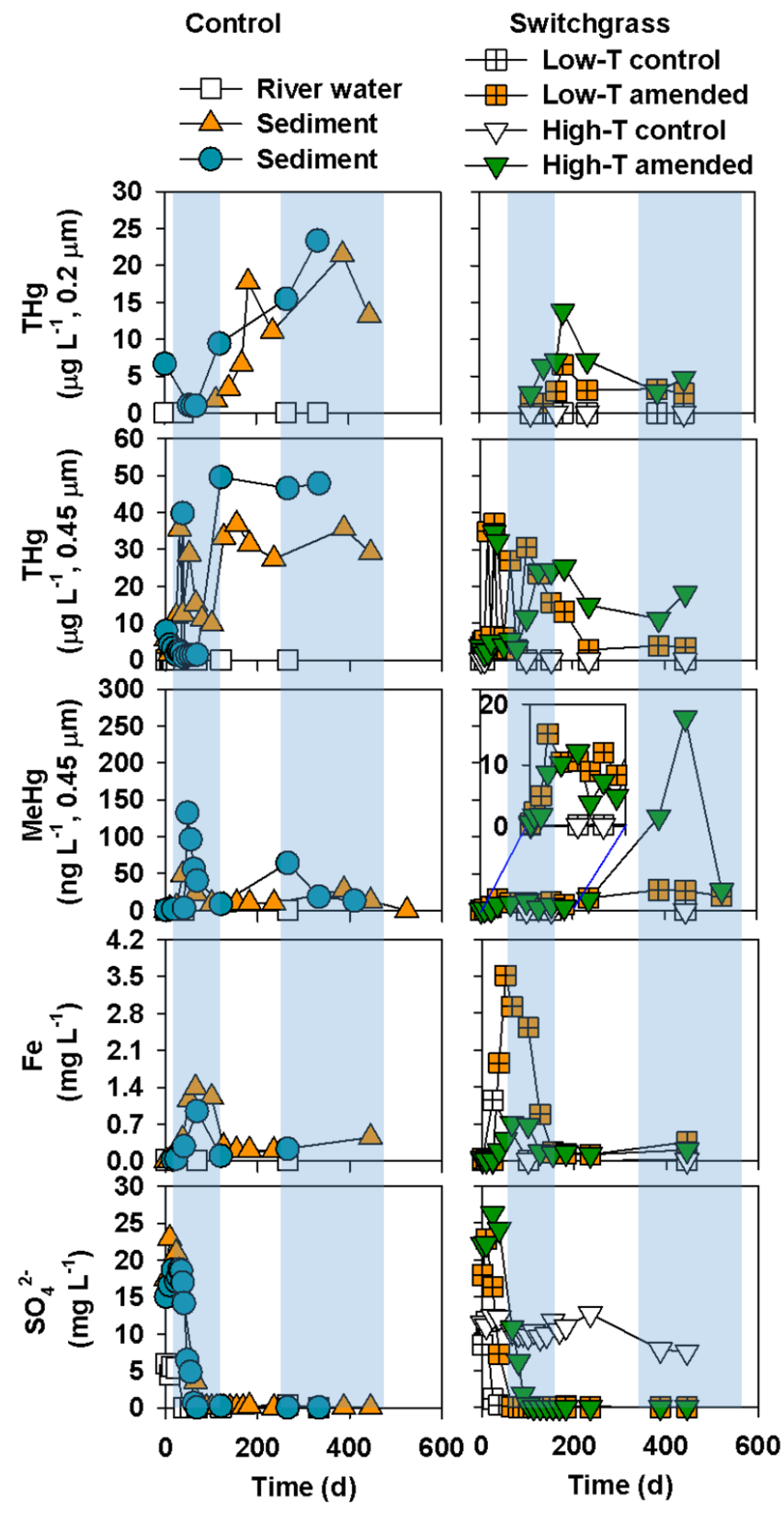

Figure 1. Concentrations of 0.2- and 0.45- $\mu \mathrm{m}$ filtered $\mathrm{THg}, \mathrm{MeHg}, \mathrm{Fe}$, and $\mathrm{SO}_{4}{ }^{2-}$ in aqueous solutions of controls and amended systems vs. time. The blue bars indicate two stages of MeHg production: a combined iron and sulfate reduction period (first) and a methanogenic period (second). 


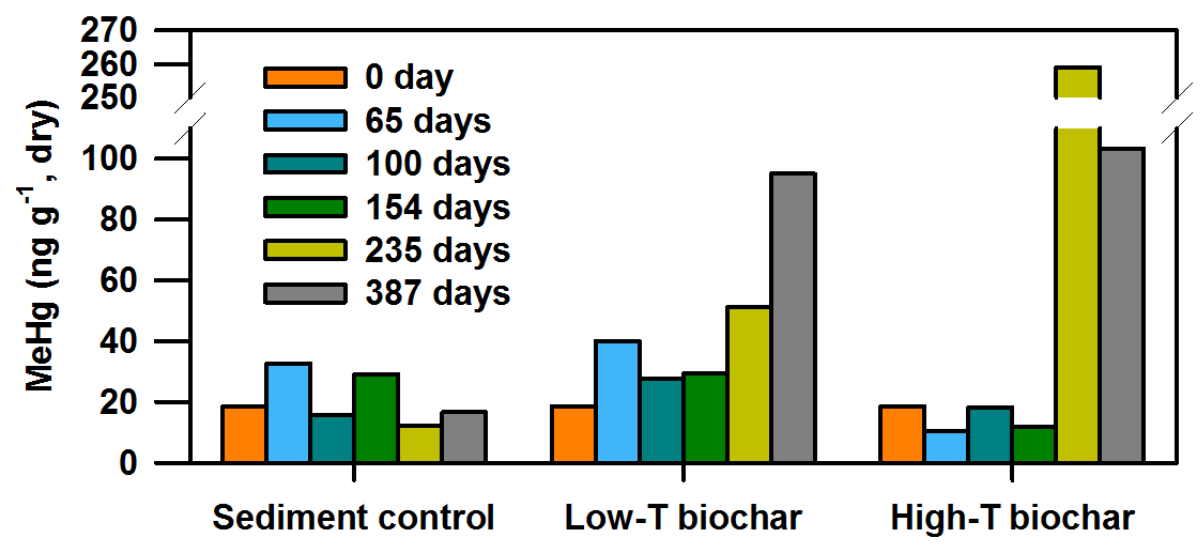

Figure 2. MeHg content in sediment control and amended systems (low-T and high-T switchgrass biochars) at day $0,65,100,154,235$, and 387. 


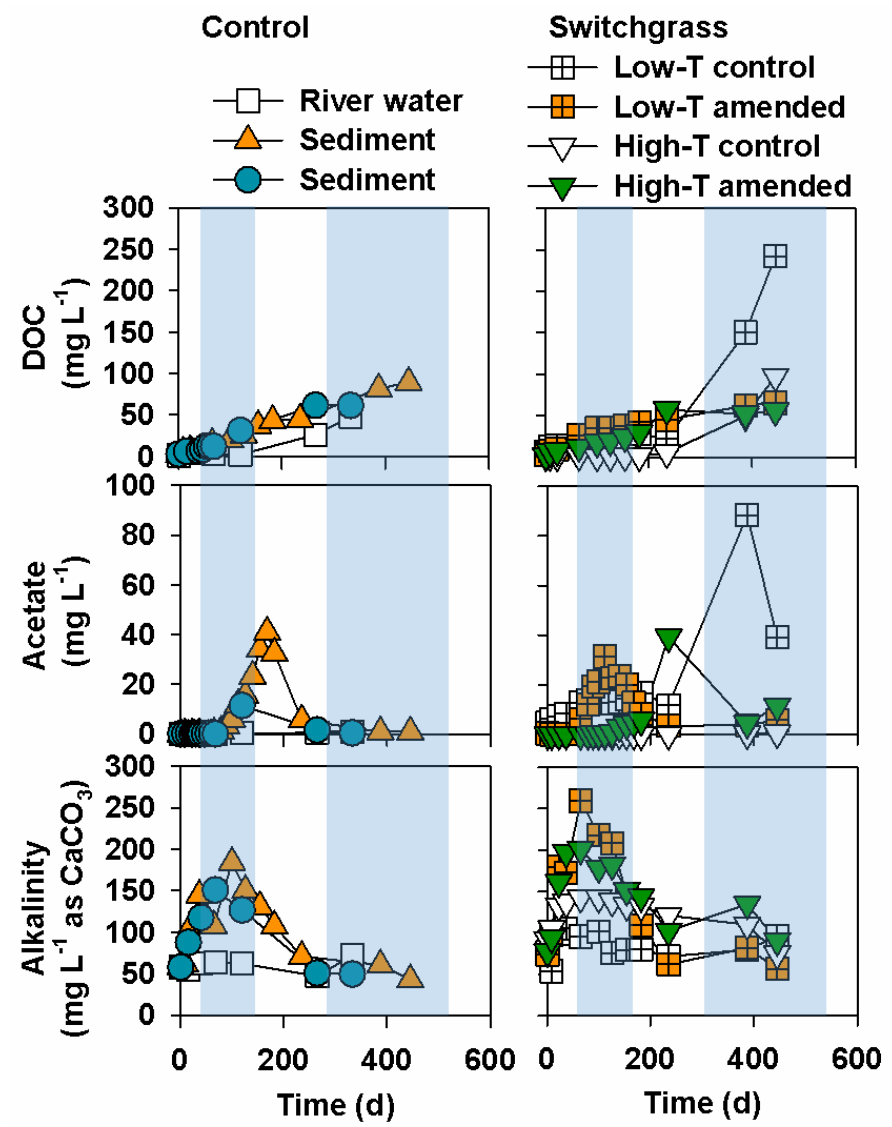

Figure 3. Carbon sources (dissolved organic carbon (DOC), acetate, and alkalinity) of controls and amended systems against time. The blue bars indicate two stages of $\mathrm{MeHg}$ production: a combined iron and sulfate reduction period (first) and a methanogenic period (second). 

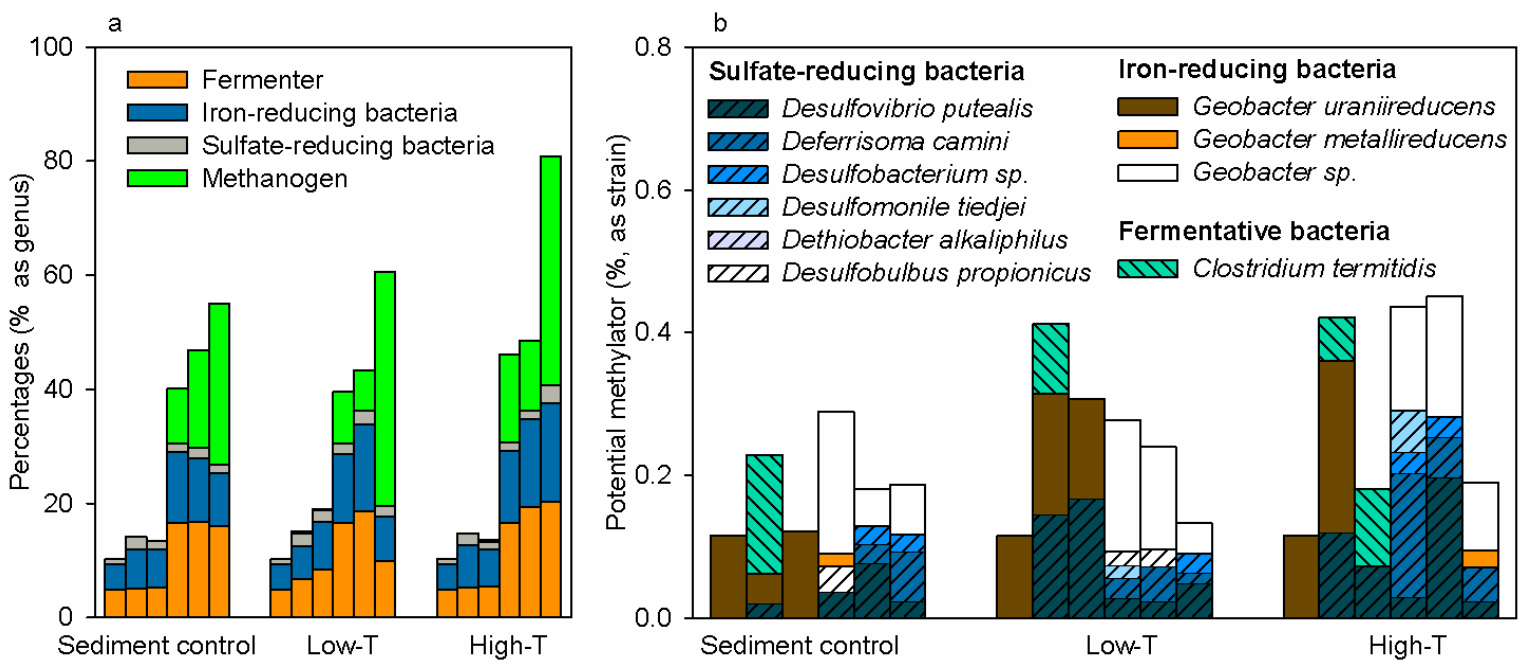

Figure 4. a, percentages of genus including fermenter, FeRB, SRB, and methanogens in sediment control and amended systems; b, percentages of species identified as known $\mathrm{Hg}$ methylators. For each sample, bars in the graphs represents, from left to right, samples collected on days $0,65,100,154,235$, and 387 , respectively. 


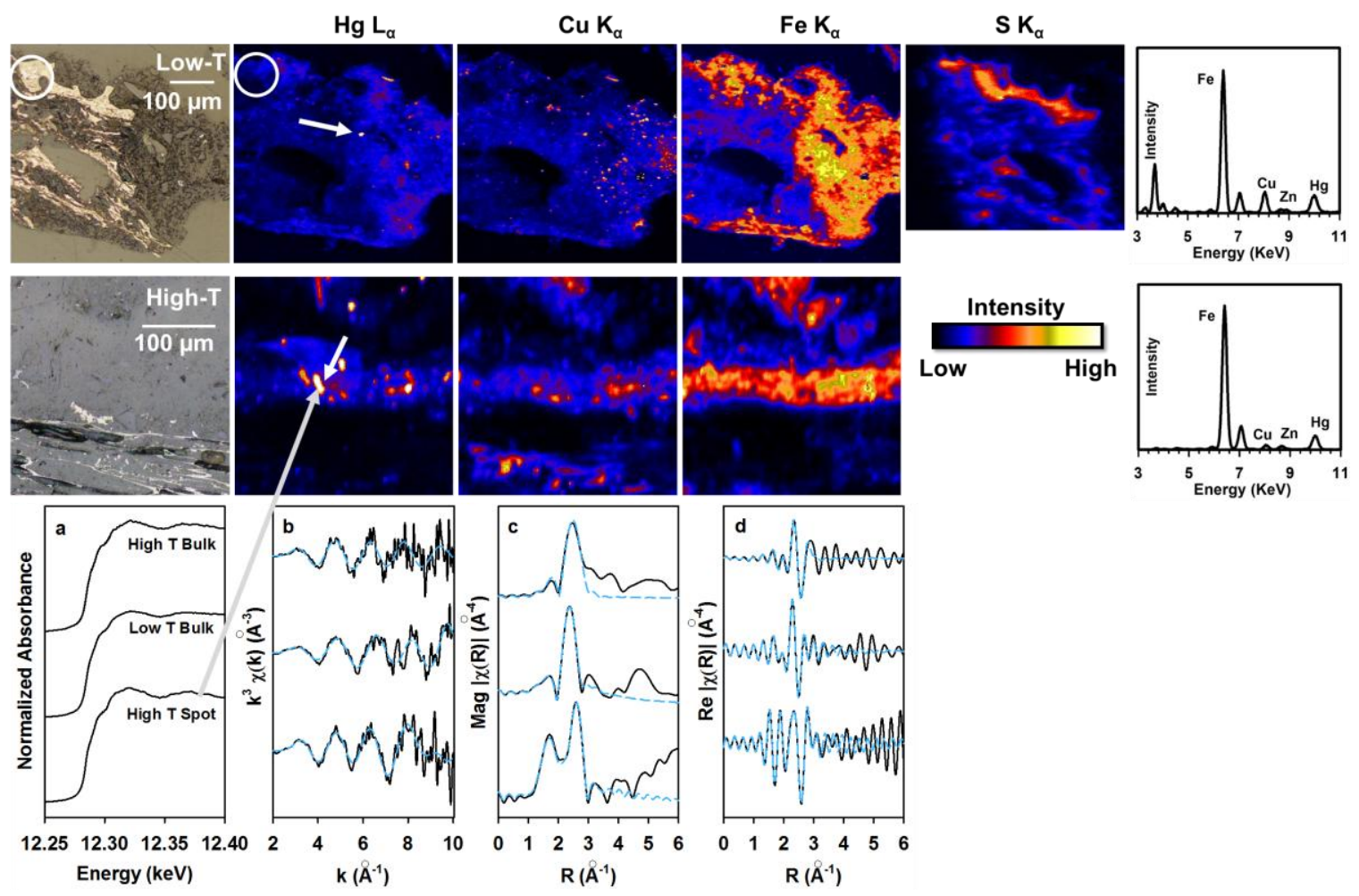

Figure 5. Micro-XRF maps ( $\mathrm{Hg}, \mathrm{Cu}, \mathrm{Fe}$, and $\mathrm{S}$ ) of thin-sections of low-T (top) and high$\mathrm{T}$ (intermediate) biochar particles from amended systems at day 235 and 387, respectively. The first column shows microscopic images and the last column XRF spectra were collected from the area indicated by the white arrow. The S map was collected at a different time and with a different beamline setup. ${ }^{a}$ Edge-step normalized $\mathrm{Hg} \mathrm{L}_{\mathrm{III}}$-edge XANES spectra were collected at the point indicated by the gray arrow (High-T Spot) and from bulk low-T and high-T particles from the amended system at day 387. ${ }^{\mathrm{b}} \mathrm{k}^{3}$-weighted chi spectra (black solid line) and the best fit data (light-blue dash line). ${ }^{c}$ Fourier-transform magnitude spectra and the best fit data. ${ }^{\mathrm{d}}$ Fourier-transform real part and the best fit data. 


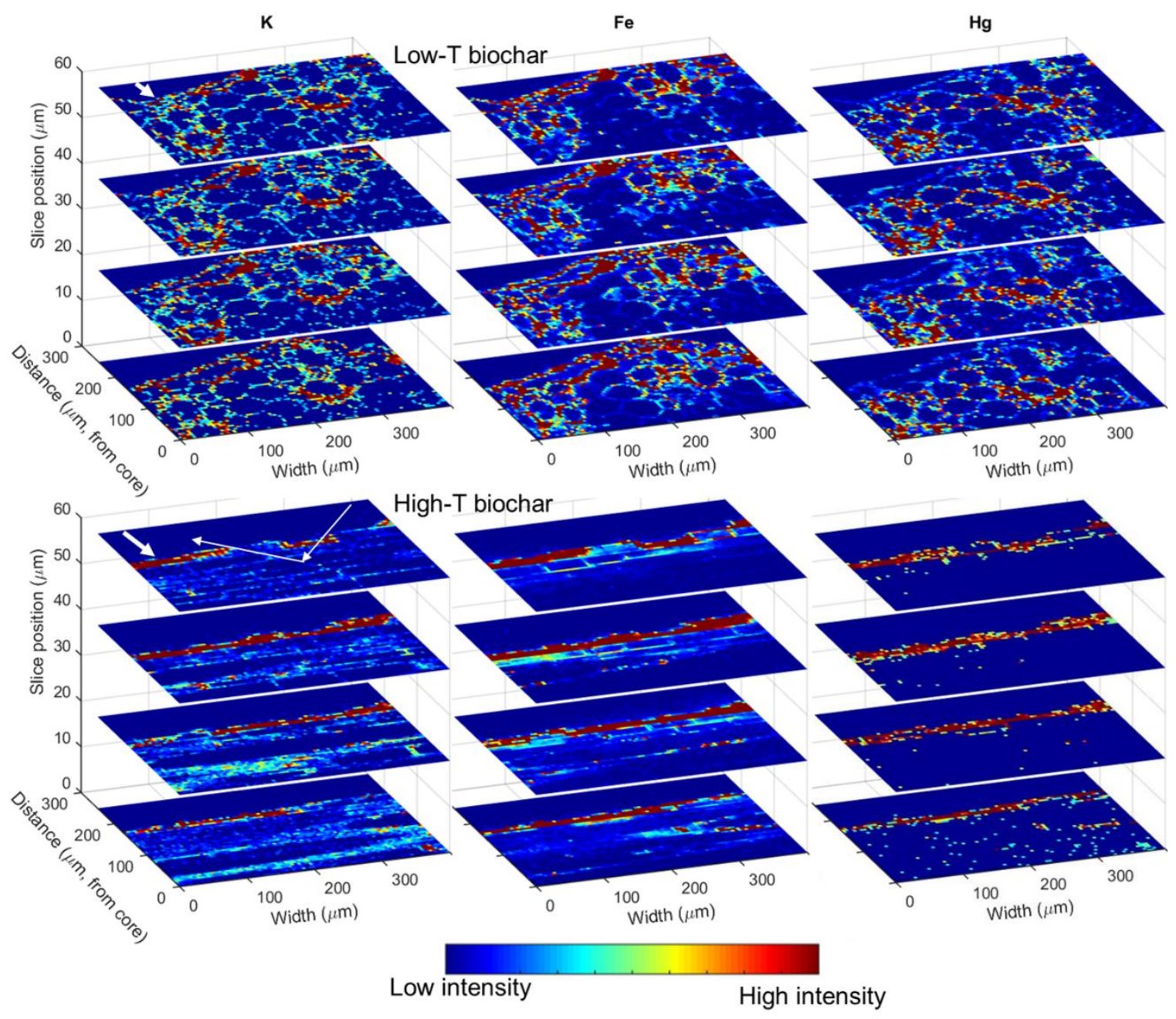

Figure 6. Confocal X-ray micro-fluorescence imaging showing the distribution of $\mathrm{K}, \mathrm{Fe}$, and $\mathrm{Hg}$ in low-T and high-T biochar particles (not physically sectioned) collected from the amended systems after $600 \mathrm{~d}$. The low-T switchgrass biochar particle was analyzed perpendicular and the high-T biochar particle was analyzed parallel to the straw, which accounts for the differences in pore structure. The thick white arrow indicates the surface of the particle. The thin white arrow indicates the incident and emitted beam paths. Note: vertical exaggeration is $\sim 7$. 


\section{References}

[1] P.B. Tchounwou, W.K. Ayensu, N. Ninashvili, D. Sutton, Environmental exposure to mercury and its toxicopathologic implications for public health, Environ. Toxicol., 18 (2003) 149-175.

[2] C.C. Gilmour, E.A. Henry, R. Mitchell, Sulfate stimulation of mercury methylation in freshwater sediments, Environ. Sci. Technol., 26 (1992) 2281-2287.

[3] H. Hu, H. Lin, W. Zheng, S.J. Tomanicek, A. Johs, X. Feng, D.A. Elias, L. Liang, B. $\mathrm{Gu}$, Oxidation and methylation of dissolved elemental mercury by anaerobic bacteria, Nat. Geosci., 6 (2013) 751-754.

[4] R.Q. Yu, J.R. Reinfelder, M.E. Hines, T. Barkay, Mercury methylation by the methanogen Methanospirillum hungatei, Appl. Environ. Microbiol., 79 (2013) 6325-6330.

[5] E.J. Kerin, C.C. Gilmour, E. Roden, M.T. Suzuki, J.D. Coates, R.P. Mason, Mercury methylation by dissimilatory iron-reducing bacteria, Appl. Environ. Microbiol., 72 (2006) 7919-7921.

[6] J. Benoit, C. Gilmour, A. Heyes, R. Mason, C. Miller, Geochemical and biological controls over methylmercury production and degradation in aquatic ecosystems, in: ACS symposium series, 2003, pp. 262-297.

[7] N.S. Bloom, B.K. Lasorsa, Changes in mercury speciation and the release of methyl mercury as a result of marine sediment dredging activities, Sci. Total Environ., 237-238 (1999) 379-385.

[8] P.M. Randall, B.J. Yates, V. Lal, R. Darlington, R. Fimmen, In-situ subaqueous capping of mercury-contaminated sediments in a fresh-water aquatic system, Part II-evaluation of sorption materials, Environ. Res., 125 (2013) 41-51.

[9] S. Serrano, D. Vlassopoulos, B. Bessinger, P.A. O'Day, Immobilization of Hg(II) by coprecipitation in sulfate-cement systems, Environ. Sci. Technol., 46 (2012) 6767-6775.

[10] C.C. Gilmour, G.S. Riedel, G. Riedel, S. Kwon, R. Landis, S.S. Brown, C.A. Menzie, U. Ghosh, Activated carbon mitigates mercury and methylmercury bioavailability in contaminated sediments, Environ. Sci. Technol., 47 (2013) 13001-13010.

[11] J.L. Gomez-Eyles, C. Yupanqui, B. Beckingham, G. Riedel, C. Gilmour, U. Ghosh, Evaluation of biochars and activated carbons for in situ remediation of sediments impacted with organics, mercury, and methylmercury, Environ. Sci. Technol., 47 (2013) 13721-13729.

[12] S.E. Bailey, T.J. Olin, R.M. Bricka, D.D. Adrian, A review of potentially low-cost sorbents for heavy metals, Water Res., 33 (1999) 2469-2479. 
[13] X.Y. Liu, A.F. Zhang, C.Y. Ji, S. Joseph, R.J. Bian, L.Q. Li, G.X. Pan, J. PazFerreiro, Biochar's effect on crop productivity and the dependence on experimental conditions-a meta-analysis of literature data, Plant Soil, 373 (2013) 583-594.

[14] K.A. Spokas, K.B. Cantrell, J.M. Novak, D.W. Archer, J.A. Ippolito, H.P. Collins, A.A. Boateng, I.M. Lima, M.C. Lamb, A.J. McAloon, R.D. Lentz, K.A. Nichols, Biochar: A synthesis of its agronomic impact beyond carbon sequestration, J. Environ. Qual., 41 (2012) 973-989.

[15] J. Lehmann, A handful of carbon, Nature, 447 (2007) 143-144.

[16] M. Ahmad, A.U. Rajapaksha, J.E. Lim, M. Zhang, N. Bolan, D. Mohan, M. Vithanage, S.S. Lee, Y.S. Ok, Biochar as a sorbent for contaminant management in soil and water: A review, Chemosphere, 99 (2014) 19-23.

[17] M.J. Pushie, I.J. Pickering, M. Korbas, M.J. Hackett, G.N. George, Elemental and chemically specific X-ray fluorescence imaging of biological systems, Chem. Rev., 114 (2014) 8499-8541.

[18] L. Vincze, B. Vekemans, F.E. Brenker, G. Falkenberg, K. Rickers, A. Somogyi, M. Kersten, F. Adams, Three-dimensional trace element analysis by confocal X-ray microfluorescence imaging, Anal. Chem., 76 (2004) 6786-6791.

[19] S. Choudhury, J.K. Thomas, N.J. Sylvain, O. Ponomarenko, R.A. Gordon, S.M. Heald, D.M. Janz, P.H. Krone, I. Coulthard, G.N. George, I.J. Pickering, Selenium preferentially accumulates in the eye lens following embryonic exposure: A confocal x-ray fluorescence imaging study, Environ. Sci. Technol., 49 (2015) 2255-2261.

[20] N.L. Cordes, S. Seshadri, G.J. Havrilla, X. Yuan, M. Feser, B.M. Patterson, Three dimensional subsurface elemental identification of minerals using confocal micro$\mathrm{X}$-ray fluorescence and micro-X-ray computed tomography, Spectrochim Acta Part B At. Spectrosc., 103-104 (2015) 144-154.

[21] K. Nakano, K. Tsuji, Development of confocal 3d micro XRF spectrometer and its application to rice grain, Bunseki Kagaku, 55 (2006) 427-432.

[22] S. Schmitz, A. Möller, M. Wilke, W. Malzer, B. Kanngiesser, R. Bousquet, A. Berger, S. Schefer, Chemical U-Th-Pb dating of monazite by 3D-micro X-ray fluorescence analysis with synchrotron radiation, Eur. J. Mineral., 21 (2009) 927945.

[23] P. Liu, C.J. Ptacek, D.W. Blowes, W.R. Berti, R.C. Landis, Aqueous leaching of organic acids and dissolved organic carbon from various biochars prepared at different temperatures, J. Environ. Qual., 44 (2015) 684-695. 
[24] D.K. Nordstrom, Thermochemical redox equilibria of ZoBell's solution, Geochim. Cosmochim. Acta, 41 (1977) 1835-1841.

[25] T.S. Light, Standard solution for redox potential measurements, Anal. Chem., 44 (1972) 1038-1039.

[26] M. Horvat, N.S. Bloom, L. Liang, Comparison of distillation with other current isolation methods for the determination of methyl mercury compounds in lowlevel environmental samples Part 1. Sediments, Anal. Chim. Acta, 281 (1993) $135-152$.

[27] Oak Ridge National Laboratory Predicted mercury methylators. http://www.esd.ornl.gov/programs/rsfa/data/PredictedMethylators/PredictedMeth ylators_20140514.pdf.

[28] B. Ravel, M. Newville, ATHENA, ARTEMIS, HEPHAESTUS: Data analysis for Xray absorption spectroscopy using IFEFFIT, J. Synchrotron Radiat., 12 (2005) 537-541.

[29] B.D. Gibson, C.J. Ptacek, M.B.J. Lindsay, D.W. Blowes, Examining mechanisms of groundwater $\mathrm{Hg}(\mathrm{II})$ treatment by reactive materials: An EXAFS study, Environ. Sci. Technol., 45 (2011) 10415-10421.

[30] P. Liu, C.J. Ptacek, D.W. Blowes, R.C. Landis, Mechanisms of mercury removal by biochars produced from different feedstocks determined using X-ray absorption spectroscopy, J. Hazard. Mater., 308 (2016) 233-242.

[31] A.R. Woll, D. Agyeman-Budu, D.H. Bilderback, D. Dale, A.Y. Kazimirov, M. Pfeifer, T. Plautz, T. Szebenyi, G. Untracht, 3D x-ray fluorescence microscopy with $1.7 \mu \mathrm{m}$ resolution using lithographically fabricated micro-channel arrays, in: S. Goto, C. Morawe, A.M. Khounsary (Eds.) Advances in X-Ray/EUV Optics and Components VII, Proceedings of SPIE, San Diego, California, USA, 2012, pp. 85020K-85021-85020K-85014.

[32] A.R. Woll, D. Agyeman-Budu, S. Choudhury, I. Coulthard, A.C. Finnefrock, R. Gordon, E. Hallin, J. Mass, Lithographically-fabricated channel arrays for confocal x-ray fluorescence microscopy and XAFS, J. Phys. Conf. Ser., 493 (2014) 012028.

[33] W.H. McMaster, N.K. Del Grande, J.H. Mallett, J.H. Hubbell, Compilation of x-ray cross sections, Lawrence Livermore National Laboratory Report UCRL-50174 (section I-III), 1969.

[34] A. Bernaus, X. Gaona, J.M. Esbrí, P. Higueras, G. Falkenberg, M. Valiente, Microprobe techniques for speciation analysis and geochemical characterization of mine environments: The mercury district of Almadén in Spain, Environ. Sci. Technol., 40 (2006) 4090-4095. 
[35] B. Gu, B. Mishra, C. Miller, W. Wang, B. Lai, S.C. Brooks, K.M. Kemner, L. Liang, $\mathrm{X}$-ray fluorescence mapping of mercury on suspended mineral particles and diatoms in a contaminated freshwater system, Biogeosciences Discuss., 11 (2014) 7521-7540.

[36] C. Tiffreau, J. Lützenkirchen, P. Behra, Modeling the adsorption of mercury(II) on (hydr)oxides. I. amorphous iron oxide and $\alpha$-quartz, J. Colloid Interface Sci., 172 (1995) 82-93.

[37] B.A. Poulin, G.R. Aiken, K.L. Nagy, A. Manceau, D.P. Krabbenhoft, J.N. Ryan, Mercury transformation and release differs with depth and time in a contaminated riparian soil during simulated flooding, Geochim. Cosmochim. Acta, 176 (2016) 118-138.

[38] T.M. McCollom, Methanogenesis as a potential source of chemical energy for primary biomass production by autotrophic organisms in hydrothermal systems on Europa, J. Geophys. Res.-Planet, 104 (1999) 30729-30742.

[39] R.Q. Yu, J.R. Flanders, E.E. Mack, R. Turner, M.B. Mirza, T. Barkay, Contribution of coexisting sulfate and iron reducing bacteria to methylmercury production in freshwater river sediments, Environ. Sci. Technol., 46 (2012) 2684-2691.

[40] J.E. Kilduff, T. Karanfil, Y.P. Chin, W.J. Weber Jr, Adsorption of natural organic polyelectrolytes by activated carbon: A size-exclusion chromatography study, Environ. Sci. Technol., 30 (1996) 1336-1343.

[41] J.E. Kilduff, A. Wigton, Sorption of TCE by humic-preloaded activated carbon: Incorporating size- exclusion and pore blockage phenomena in a competitive adsorption model, Environ. Sci. Technol., 33 (1999) 250-256.

[42] L. Ding, V.L. Snoeyink, B.J. Mariñas, Z. Yue, J. Economy, Effects of powdered activated carbon pore size distribution on the competitive adsorption of aqueous atrazine and natural organic matter, Environ. Sci. Technol., 42 (2008) 1227-1231.

[43] S. Agarwal, I. Tyagi, V.K. Gupta, M. Ghaedi, M. Masoomzade, A.M. Ghaedi, B. Mirtamizdoust, Kinetics and thermodynamics of methyl orange adsorption from aqueous solutions - Artificial neural network-particle swarm optimization modeling, J. Mol. Liq., 218 (2016) 354-362.

[44] R.A. Berner, Early Diagenesis: A Theoretical Approach, Princeton University Press, Princeton, New Jersey, USA, 1980.

[45] E. Torres, R.M. Couture, B. Shafei, A. Nardi, C. Ayora, P. Van Cappellen, Reactive transport modeling of early diagenesis in a reservoir lake affected by acid mine drainage: Trace metals, lake overturn, benthic fluxes and remediation, Chem. Geol., 419 (2015) 75-91. 
[46] K. Yoshimura, T. Hama, Degradation and dissolution of zooplanktonic organic matter and lipids in early diagenesis, J. Oceanogr., 68 (2012) 205-214.

[47] S. Opsahl, R. Benner, Early diagenesis of vascular plant tissues: Lignin and cutin decomposition and biogeochemical implications, Geochim. Cosmochim. Acta, 59 (1995) 4889-4904.

[48] K.A. Spokas, Review of the stability of biochar in soils: Predictability of O:C molar ratios, Carbon Manag., 1 (2010) 289-303.

[49] T. Zhang, B. Kim, C. Levard, B.C. Reinsch, G.V. Lowry, M.A. Deshusses, H. HsuKim, Methylation of mercury by bacteria exposed to dissolved, nanoparticulate, and microparticulate mercuric sulfides, Environ. Sci. Technol., 46 (2012) 69506958.

[50] G.V. Lowry, S. Shaw, C.S. Kim, J.J. Rytuba, G.E. Brown, Macroscopic and microscopic observations of particle-facilitated mercury transport from New Idria and Sulphur Bank mercury mine tailings, Environ. Sci. Technol., 38 (2004) 51015111. 


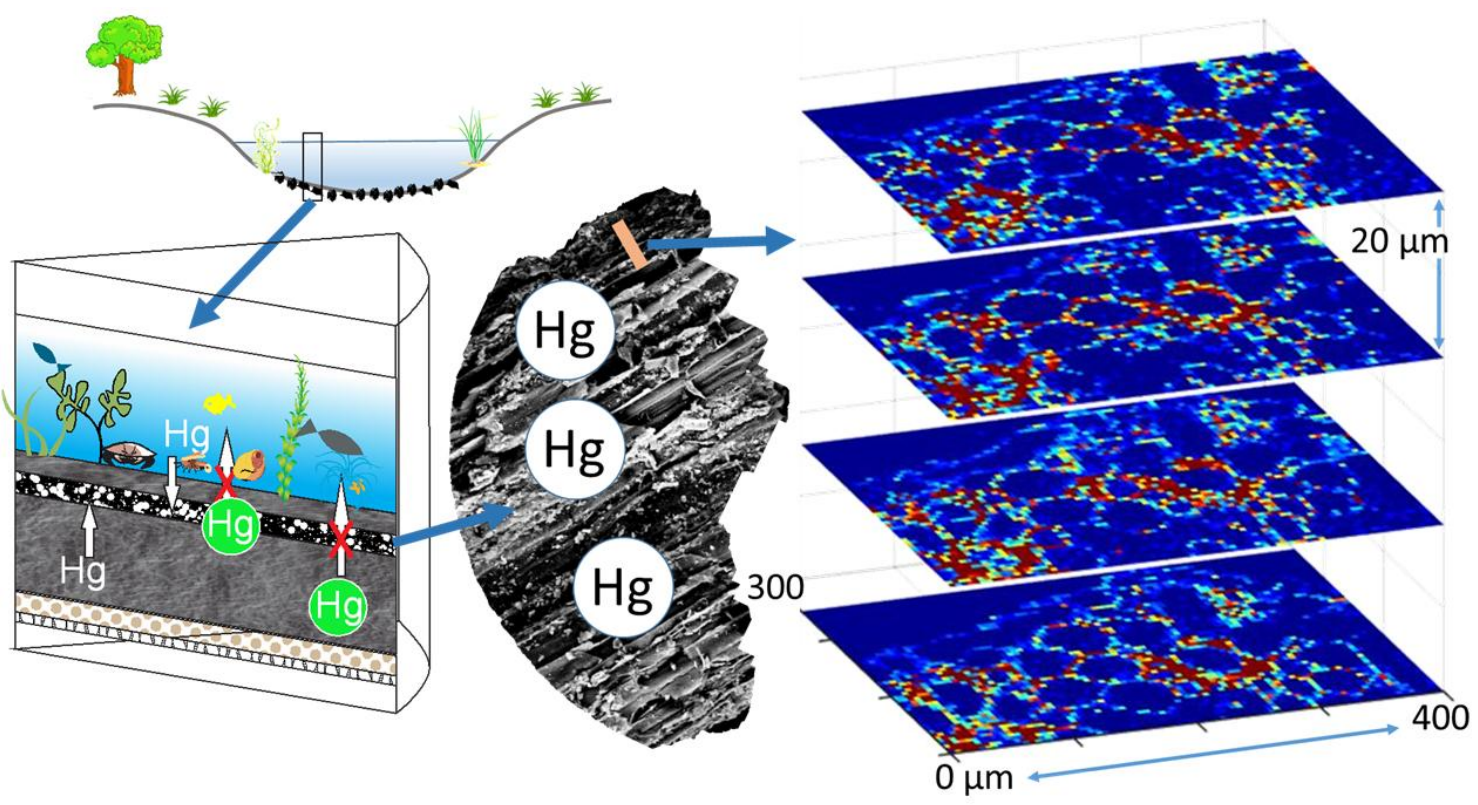

